\title{
Analysis of Non-Financial Determinants of Company Value In Manufacturing Companies in Indonesia
}

\author{
Dwi Asih Surjandari, Dewi Anggraeni, Deby Pratiwi Arlita, and Riris Marintan \\ Purba \\ Faculty of Economic, Mercubuana University \\ Email:Dwi.asih@mercubuana.ac.id
}

\begin{abstract}
This study aims to investigate the nonfinancial determinants of Firm Value of manufacturing firms listed in the Indonesia Stock Exchange year 2013 up to 2017 period. The determinants represented by Good Corporate Governance (GCG), Firm Size, Dividend, Inflation Rate, Exchange Rate and Corporate Social Responsibility (CSR). The sampling method used purposive sampling and the analysis used Eviews 9.0 version. The study result shows that only one variable significantly affects Firm Value which is Institutional Ownership as proxied of GCG and the rest variables that are Independent Board another proxied of GCG, Firm Size, Dividend, Inflation Rate, Exchange Rate, and CSR does not significantly affect the Firm Value. All independent variables significantly affect Firm Value weakly simultaneously. This study implies that in formulating firm improvement performance strategy, a manufacturing firm is suggested to consider nonfinancial determinants of firm value that is Good Corporate Governance (GCG), Firm Size, Dividend, Inflation Rate, Exchange Rate and Corporate Social Responsibility (CSR).
\end{abstract}

Keywords: Nonfinancial Determinants, Firm Value.

\section{INTRODUCTION}

Management strives to maximize Company Value (CV) which is a measure of the success of its performance (Santos and Brito, 2012). In addition to management, the parties interested in the company include the owner of the company in which the CV describes the level of welfare to be achieved, investors can obtain information about the rate of return on investment funds, creditors obtain guaranteed loan repayment provided. The Directorate General of taxes as a governmental agency can calculate taxation obligations. Hence, CV is important for the life of the economy so the study of Company Value becomes important.

This study examines determinants of company value beyond finance which the result of previous studies vary by including Good Corporate Governance, Corporate Social Responsibility, and Firm Size Dividend variables (Hsin Lu et al., 2010) Inflation and Exchange Rates (Karakus and Bozkurt), 2017) with the title Non-Financial Determinant Analysis of Company Value, Case Study of Manufacturing Companies Listed on the Indonesia Stock Exchange in 2013-2017. 


\section{THEORETICAL REVIEW}

Agency Theory. Agency theory is an old theory that deals with problems with agents and how to solve them where agency problems arise due to differences in interests between agent and principal. Meanwhile, the appointment of an agent is with a mission that makes the principal more prosperous in the form of high performance (Brigham and Houston, 2012), one of which appears in Corporate Value.

Stakeholder Theory. Dr. F. Edward Freeman, the originator of stakeholder theory, defines this theory as Stakeholder Theory is "any group or individual who can affect or is affected by the achievement of the organization objectives" consisting of: customers, employees, local communities, suppliers and distributors and owners company, such as all parties with an interest in the company. Management in running a company to maximize Company Value must consider these stakeholders.

The value of the company. (Brigham and Houston, 2012) stated that the company's value is determined by market perceptions of the sustainability of the company's performance as shown in the market price of the shares outstanding on a certain date that can be measured, among others, by Tobin's Q, Market Value Added (MVA), Market to Book Value (MTBV) and the most chosen market value measure as an indicator is Tobin's Q. formula (Al Matari et all., 2014) which is calculated from the ratio of the total market value of the firm / total asset value of the firm (Hayes, 2019 ).

Good Corporate Governance. Good Corporate Governance (GCG) is a system that regulates and controls companies in creating value-added for all stakeholders whose implementation is based on the following principles: Transparency, Accountability, Responsibility, Independence and Fairness (Amirudin el all., 2017 ); (Wan Yusof et all., 2012), (Monks and Minow, 2003). The 5 basic principles must exist in all company systems that are applied to increase added value for all stakeholders. Considering that management is a party that implements the principles of GCG, supervision is a necessity which in practice can be characterized by the presence of an Independent Board (IB) and Institutional Ownership (IO) which in this study are used as a proxy for GCG mechanisms. Studies related to the effect of GCG on CVs results are still mixed. Various studies for OIs were found in (Jamil et all., 2016) with the result of Institutional Investors having a significant positive effect, but Government Ownership had a significant negative effect on company performance. (Azutoru et all., 2017) indicated that with the result of IO and IB has a significant positive effect on the CV. While (Zabri et all., 2016) stated there is no relationship between IB and Company Performance; Studies by (Irma et all., 2015), (Iwan et all., 2016), (Sigit, 2015); (Sigit and Winwin, 2016) revealed that with IB result have a significant positive effect on performance, but significant negative result was found in the study b y (Zabri et all., 2016) while result with no effect was found in (Suryanto and Meisa, 2016).

Corporate Social Responsibility. The Australian Human Rights Commission defines "is generally understood to mean that corporations have a degree of responsibility not only for the economic consequences of their activities but also for social and environmental 
implications. CSR aims to ensure that the company conducts its business in an ethical manner, in the sense of considering environmental, economic and social impacts and human rights in each of its activities which can be: working with local communities, spending social funds, developing cooperation with trade unions and customer groups as well as concern for environmental protection and sustainability (Chin and Rupp, 2018). One proof that the company has carried out activities related to CSR is the disclosure in company reports commonly known as sustainability reporting. The study by (Wiwik, 2015) concluded that there is a relationship between the quality of CSR disclosure and Company Value, therefore the CSR proxy in this study is CSR disclosure in company reports. In theory, (Hamidu et all., 2015) stated that the concepts in CSR enable management to use CSR as a tool to increase profitability while increasing Company Value. Research with the result that CSR has a significant positive effect on Company Value is found in (Amirudin et all., 2017), (Kumar and Priyadarsini, 2017), (Chung et all., 2018), (Choi et all., 2018), but research by (Al Hasan et all., 2013) have a significant negative effect and the opposite results are found (Hafez, 2016). While Selvarajah et al. (2018) stated that only a portion of CSR activities affect Company Value, while (Chen and Hsun, 2017) obtain the result that CSR activities will not increase CV to the transition threshold.

Company Size. Company size (CS) is related to the size of a company which in literature is often shown from net sales or total assets, the average value of total assets, the book value of total assets or the value of the company itself. (Dang and Li, 2015) in their theoretical study stated that company size affects the results, the bigger the company, the bigger the results and vice versa, where company size can be measured by total sales, total assets and other sizes, wherein this study, UP is seen from ln total assets. Studies with the result that company size affects performance are found in (Oyelade, 2019), (Luqman et all., 2013), (Dogan, 2013), (Yisau, 2013), but research by (Niresh and Velhampy, 2014) stated that does not affect.

Dividend. Dividends are payments of a portion of profits from a company to shareholders, where dividend payments are one of the information awaited by shareholders because investors perceive that dividend payments are an indication of the company's financial health as a representative of the company's value (Rajhans, 2013). Research controversies related to the effect of dividend policy on performance found in research (Ali et all., 2015), (Al Hasan et all., 2013) have a significant positive effect, (Ahmad et all., 2018) significant negative effect, while (Irandoost et all., 2013) the result have a significant effect only in the short term and (Ayako and Walmawa, 2015) with the result do not affect the Firm Value. In this study, the dividend variable is proxied by the amount of the Dividend Pay Out Ratio.

Inflation Rate (IT). Inflation is a continuous increase in the prices of goods and services in a certain period, where this inflation affects the economy in general and companies in particular positively and negatively (John and Bernanke, 2005). The negative effect is seen in studies in (Zulfiqar and Ud Din, 2015) where the result is that the level of inflation (IT) has a significant effect on Return on Assets (ROA) but not significantly on Return on Equity (ROE). While (Ifeanyi and Chukwuma, 2016) stated that the strong negative 
relationship between IT and Company Value (CV), but not significant to ROA, however (Rostami and Mosavi, 2016) produced findings that IT improved and increased company profitability. This variable Inflation is proxied with annual average inflation from the Central Bureau of Statistics (BPS).

Exchange rate. The exchange rate (ER) is the price of a country's currency that is converted to another country's currency. Bearing in mind that the currency that dominates the world including Indonesia is the US Dollar, the exchange rate in this study is the exchange rate of the US dollar and the average rupiah obtained from Bloomberg. (Hyo, 2018) explained that the influence of NT on positive or negative company performance depends on its involvement in import-export activities at the macro level, but also influenced by industry and company level analysis. Empirical studies of the effect of ER on CVs have produced mixed findings. (Hyo, 2018) produced a finding that a group of companies that were positively affected by NT appreciation experienced a rise in NP in the short term, but there were a group of companies that were negatively affected due to ER appreciation, apparently experiencing an increase in the CV in the medium and long term. (Lee, 2017) indicated that produces findings that ER appreciation does not cause a decrease in the level of investment, while (Williams, 2018) stated that there is a positive relationship between ER and ROI, while (Nagahisarchoghani et all., 2018) stated there is a weak relationship between ER and prices per book stock/ per market price, however (Okika et all., 2018) makes finding that NT has no significant effect on company profitability.

Framework for Thinking and Hypothesis. In theory, the mechanism of Good Corporate Governance (GCG) will have a positive effect on Company Value (CV) because GCG is a system that regulates and controls the company in creating value-added for all stakeholders which implementation is based on the following principles: Transparency, Accountability, Responsibility, Independence and Fairness (Amirudin et all., 2017), (Wan Yusof and Alhaji, 2012), (Monks and Minow, 2003). Considering that management is a party that implements the principles of GCG, supervision is a necessity which in practice can be characterized by the presence of an Independent Board (IB) and Institutional Ownership (IO) which in this study are used as a proxy for GCG mechanisms. Meanwhile studies with the result of Institutional Ownership (IO) have a significant positive effect on Company Value (CV) found in (Jamil et all., 2016) and (Azutoru et all., 2017) and Independent Board (IB) have a significant positive effect found in studies by (Irma et all., 2015), (Iwan et all., 2016), (Sigit, 2015), (Sigit and Winwin, 2016).

Therefore the hypothesis is proposed: H1: Independent Board has a significant positive effect on Company Value and H2: Institutional Ownership has a significant positive effect on Company Value. (Dang and Li, 2015) in their theoretical study stated that Company Size (CS) affects the result, the greater the company the greater the results and vice versa, support for the statement found in studies by (Oleyade, 2019); (Luqman et all., 2013); (Dogan, 2013) and (Yisau, 2013).

Therefore the hypothesis is proposed: H3: Firm size has a significant effect on firm value. Related to the positive influence of dividends on $\mathrm{CV}$, it is theoretically explained that dividends are one of the information awaited by shareholders because investors perceive dividend payments as an indication of the company's financial health as a 
representation of the value of the company (Rajhans, 2013) in which is supported studies by (Ali et all., 2015), (Al Hasan et all., 2013).

Based on this hypothesis H4 indicated that: Dividend has a significant effect on firm value. The Influence of Inflation (IT) on the CV can be positive or negative (John and Bernanke, 2005), where this theory appears in studies of (Zulfiqar and Ud Din, 2015); (Ifeanyi et all., 2016); (Rostami and Mosavi, 2016).

Therefore the hypothesis is proposed: H5: The level of inflation has a significant effect on firm value. (Hyo Sang, 2018) explained that the effect of ER on positive or negative company performance depends on its involvement in import-export activities at the macro level and industry and company level analysis. Studies with the result that ER has a significant effect on CV were found in (Lee, 2017), (Williams, 2018), (Nagahisarchoghani et all., 2018), (Hyo Sang, 2018) and (Karakus and Bozkurt, 2017).

Based on the description is conveyed hypothesis: H6: Exchange Rates have a significant effect on Company Value. Related to the influence of CSR on CV, (Hamidu et all., 2015) stated that the concepts in CSR enable management to use CSR as a tool to increase profitability, while increasing CV, so CSR has a positive effect on the CV. Support for this statement was found in studies from (Amirudin et all., 2017); (Kumar and Priyadarsini, 2017); (Chung et all., 2018); (Choi et all., 2018).

Therefore based on the descriptions, the hypothesis is presented: H7: CSR has a significant positive effect on Company Value. The relationship of all these variables can be shown in Figure 1 below:

Figure 1. Framework for Thinking

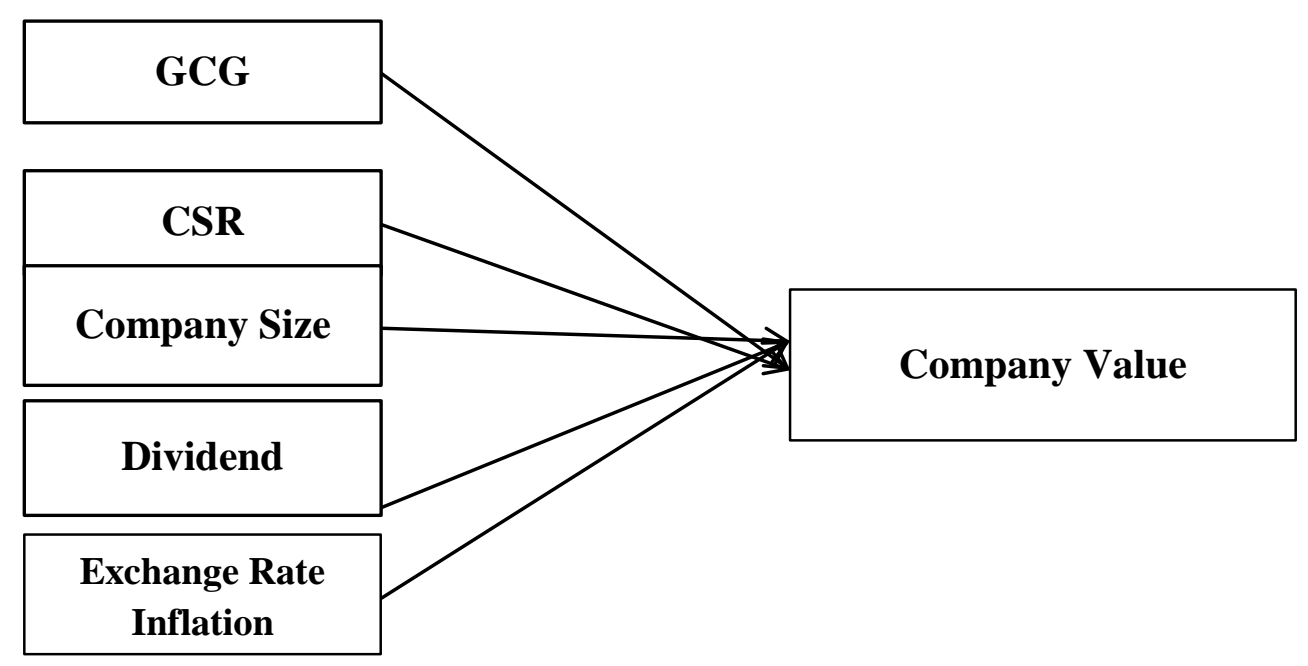

\section{METHODOLOGY}

Research design. This type of research is explanatory research (Gendro, 2011) which aims to test the hypothesis about the effect of one or several variables (independent variables) on other variables (the dependent variable). The independent variables used are 
GCG, CSR, Company Size, Dividends, Inflation and Exchange Rates while the dependent variable is Company Value.

Research Subjects. Research subjects or populations in this research are manufacturing companies listed on the Indonesia Stock Exchange (IDX) from 2013 to 2017. Following population criteria and research objectives, the sampling method used is purposive sampling (Gendro, 2011), with the determination of the number of samples based on the Slovin formula with a $10 \%$ error rate. The number of manufacturing companies listed on the IDX is 131 companies so that $\mathrm{n}$ population $5 \times 131=655$, so $\mathrm{n}$ samples $=655 /(1+$ $655 \mathrm{x} 0.12)=655 / 7.55=87$, rounded to 90 , thus the number of samples is 18 companies every year observation.

Research Process Flow. This study includes explanatory research that explains the causal relationship between variables through hypothesis testing. Some things that will be discussed include research objects, research methods, populations and samples, types and sources, data collection techniques, data testing, and data analysis methods, as summarized in the fishbone diagram research flowchart, as follows:

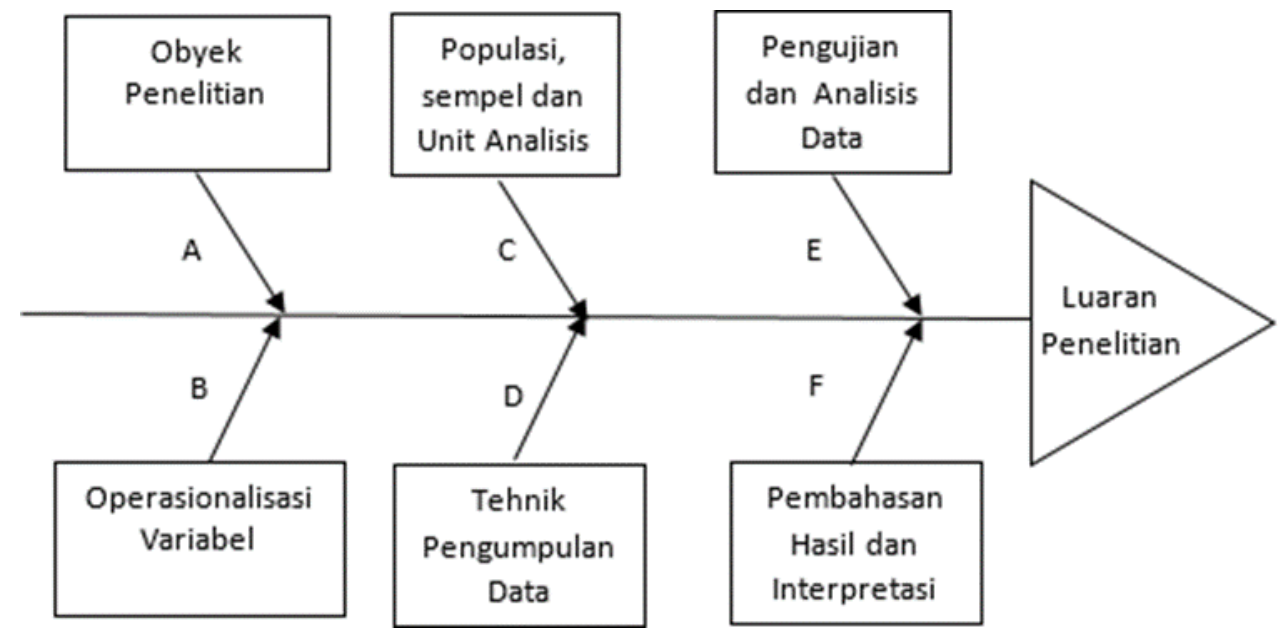

Note:
A. Objek penelitian: Research Object
B. Operasionalisasi variabel: variable operationalization
C. Populasi, sampel dan unit analisis: Population, sample and analysis unit
D. Teknik Pengumpulan Data: Data collection technique
E. Pengujian dan Analisis Data: Testing and Data Analysis:
F. Pembahasan Hasil dan Interpretasi: Discussion of Result and Interpretation
G. Luaran Penelitian: Research Output

\section{Definition of Variable Operations}

The operationalization of the research variables is explained in the following table 1: 
Table 1. Operationalization of Variables

\begin{tabular}{c|c|c|c}
\hline Variable & DIMENSION & INDICATOR & SCALE \\
\hline GCG & Non-Financial & $\begin{array}{c}\text { Independent Board Proportion } \\
\text { Institutional Ownership Proportion } \\
\text { Ratio }\end{array}$ & Ratio \\
\hline CSR & Non-Financial & GRI Disclosure & Ratio \\
\hline Company Size & Non-Financial & Ln Total Asset & Ratio \\
\hline Deviden & Non-Financial & Deviden Pay Out Rasio & Ratio \\
\hline Exchange Rate & Non-Financial & Average inflation rate & Average Exchange Rates \\
\hline
\end{tabular}

Source: (Processed Data, 2019)

Analysis Method. Because the data to be tested is panel data, the data analysis used is regression analysis with the E-views program version 9.0 (Lela, 2018) with the following stages: a) Descriptive Statistical Analysis, b) Classical Assumption Test includes the test: Normality, Multicollinearity, Heteroscedasticity and Autocorrelation, c) Hypothesis Tests include: Determination Coefficient Analysis $\left(\mathrm{R}^{2)}\right.$, F Test and Statistical F Test, t-Test.

\section{RESULT AND DISCUSSION}

Description of Research Object. The object of research is manufacturing companies listed on the Indonesia Stock Exchange which published financial statements from 2014 to 2018. The number of manufacturing companies listed on the IDX is 131 companies so that the population $131 \times 5=655$, determining the number of samples taken with the Slovin formula with the level of error of $10 \%, \mathrm{n}$ samples $=655 /(1+(655 \times 0.12))=655 / 7.55=$ 87 , rounded up to 90 and based on the purposive sampling criteria obtained a sample of 18 companies from various sectors.

Description Analysis. Description analysis describes the description of a data that is seen from the average (mean), maximum, minimum and standard deviation of each variable (Ghozali, 2006).

The dependent variable used in this study is Company Value measured by Tobin's Q, while the independent variable consists of the Good Corporate Governance mechanism represented by the Independent Board as measured by the proportion of independent commissioners and Institutional Ownership as measured by the proportion of share ownership by the institution, Corporate Social Responsibility (CSR) measured from the GRI index score, Dividend Pay Out Ratio (DPR) as measured by the proportion of dividend payments, Exchange Rate is measured by an average exchange rate of \$US against Rupiah, Size measured in total assets and Inflation Rate measured by average inflation annually as shown in table 2 . 
Table 2. Test Result of Descriptive Statistics

\begin{tabular}{|c|c|c|c|c|c|c|c|c|}
\hline & FIRM_VALUE & INDEPEND... & INSTITUTIO... & CSR & DPR & NILAI_TUKAR & SIZE & TINGKAT_I... \\
\hline Mean & 2.781847 & 0.385344 & 0.699301 & 0.091819 & 0.436974 & 13500.80 & 29.03219 & 4.294000 \\
\hline Median & 1.677996 & 0.400000 & 0.746359 & 0.065934 & 0.402341 & 13555.00 & 28.90107 & 3.350000 \\
\hline Maximum & 22.55938 & 0.750000 & 0.962097 & 0.472527 & 2.248694 & 14300.00 & 31.86654 & 8.360000 \\
\hline Minimum & 0.074034 & 0.000000 & 0.139680 & 0.010989 & -2.009958 & 12388.00 & 25.61948 & 3.020000 \\
\hline Std. Dev. & 4.158162 & 0.128769 & 0.190096 & 0.082008 & 0.587571 & 630.1266 & 1.620272 & 2.054449 \\
\hline Skewness & 3.239885 & -0.972501 & -1.084677 & 2.508134 & -0.256576 & -0.685837 & -0.126227 & 1.463887 \\
\hline Kurtosis & 13.32699 & 5.872591 & 3.886706 & 11.04126 & 8.456362 & 2.527332 & 2.160563 & 3.200731 \\
\hline Jarque-Bera & 557.3780 & 45.13054 & 20.59630 & 336.8428 & 112.6320 & 7.893382 & 2.881453 & 32.29556 \\
\hline Probability & 0.000000 & 0.000000 & 0.000034 & 0.000000 & 0.000000 & 0.019319 & 0.236756 & 0.000000 \\
\hline Sum & 250.3662 & 34.68095 & 62.93705 & 8.263736 & 39.32768 & 1215072. & 2612.897 & 386.4600 \\
\hline Sum Sq. Dev. & 1538.838 & 1.475759 & 3.216157 & 0.598554 & 30.72638 & 35338298 & 233.6502 & 375.6478 \\
\hline Observations & 90 & 90 & 90 & 90 & 90 & 90 & 90 & 90 \\
\hline
\end{tabular}

Source: (Output Eviews Version 10, 2019)

Number of samples $(\mathbf{N})$. The number of samples there are 90 manufacturing companies listed on the Stock Exchange for 5 consecutive years consisting of Firm Value, Independent board, Institutional Ownership, CSR, Parliament, Exchange Rates, Size, and Inflation Rate.

Company Value. Company Value has a Minimum value of 0.0740 , owned by PT. Indomobil Sukses International (Tbk) in 2017 and a maximum value of 22.5594 owned by PT Unilever Indonesia (Tbk) in 2017 with an average value of 2.781852 and a variation of the average (standard deviation) of 4.1581595 . With a mean of 2.781852 measured with Tobin's Q shows that the prospects for manufacturing companies are very good.

Independent Board. Independent Board has a minimum value of 0,000, which is owned by PT. Unilever Indonesia (Tbk) in 2014-2018 and a maximum value of 0.7500 owned by PT Tempo Scan Pacific (Tbk) in 2014. With an average value of 0.385334 and a variation of the average (standard deviation) of 0,1287768 . With a mean of 0.385334 , it shows that the proportion of the Independent Board is quite large, almost $40 \%$ of the entire board.

Institutional Ownership. Institutional Ownership has a Minimum value of 0.1397 found at PT. Arwana Citra Mulia (Tbk) in 2016-2017 and a maximum value of 0.9621 owned by PT Surya Toto Indonesia (Tbk) in 2014. With an average value (mean) of 0.699309 and a variation of the average (standard deviation) 0, 1900941. Nearly $70 \%$ of the shares of manufacturing companies are owned by institutions.

Corporate Social Responsibility (CSR). CSR has a Minimum value of 0.0110 found at PT. Tempo Scan Pacific (Tbk) in 2017 and 2018 and a maximum value of 0.4725 is found in PT Indocement Tunggal Prakarsa (Tbk) in 2014. Hence, an average value of 0.091827 and a variation of the average (standard deviation) of 0.0820000 . Based on the Global Reporting Initiative Index score, CSR awareness of manufacturing companies is still very low, which is only $9 \%$. 
Dividends/ DPR/ Dividends have a Minimum value of $-2,0100$, found at PT. Indomobil Sukses International (Tbk) in 2015 and a maximum value of 2.22487 are found in PT Indocement Tunggal Prakarsa (Tbk) in 2018. With an average value of 0.436974 and a variation of the average (standard deviation) of 0,5875751 . The percentage of profits distributed as dividends to manufacturing companies is quite large at over $43 \%$.

Exchange rate. Exchange rates have a minimum value of 12388.0 found in all companies18 in 2014. And a maximum value of 14300.0 was found in all companies in 2018. With an average value (mean) of 13500,800 and an average variation (standard deviation) of 630.1266 .

Company Size/ Size. Size has a Minimum value of 25.6195 found at PT. Lionmesh Prima (Tbk) in 2015 and a maximum value of 31.8665 found in PT Gudang Garam (Tbk) in 2018. With an average (mean) value of 29.032191 and an average variation (standard deviation) of 1.6202662 . The size of the majority of manufacturing companies is on average because of the small standard deviations, which have roughly the same size.

Inflation Rate (IT). IT has a Minimum value of 3.0200, found in 18 companies in 2016 and a maximum value of 8.3600 found in 18 companies in 2014 with an average value of 4.294000 and a variation of the average (standard deviation ) amounting to 2.0544492 .

Panel Data Regression Model Estimation. In the panel data regression analysis there are 3 approaches of the regression model namely the Common Effect, Fixed Effect and Random Effect approaches. The following are the results of each approach.

Common Effect Approach. The first model of Eviews panel data regression is the Common Effect shown in Table 3 below: 
Table 3. Pooled Least Square (Common Effect)

\begin{tabular}{|c|c|c|c|c|}
\hline $\begin{array}{l}\text { Dependent Variable: FIRM_VALL } \\
\text { Method:Panel Least Squares } \\
\text { Date: } 10 / 03 / 19 \text { Time: } 21: 29 \\
\text { Sample: } 20142018 \\
\text { Periods included: } 5 \\
\text { Cross-sections included: } 18 \\
\text { Total panel (balanced) observatic }\end{array}$ & & & & \\
\hline Variable & Coefficient & Std. Error & t-Statistic & Prob. \\
\hline INDEPENDENT BOARD & -20.30426 & 2.498925 & -8.125197 & 0.0000 \\
\hline INSTITUTIONAL OWNERSHIP & 1.019182 & 1.626213 & 0.626721 & 0.5326 \\
\hline $\mathrm{CS} \bar{R}$ & 4.401753 & 4201385 & 1.047691 & 0.2979 \\
\hline DPR & 1.105321 & 0.535882 & 2.062619 & 0.0423 \\
\hline NILAI TUKAR & -0.000982 & 0.001054 & -0.932228 & 0.3540 \\
\hline SIZE & 0.546839 & 0.200329 & 2.729712 & 0.0078 \\
\hline TINGKAT_INFLASI & -0.016989 & 0.321242 & -0.052887 & 0.9580 \\
\hline$\overline{\mathrm{C}}$ & 6.465469 & 16.20950 & 0.398869 & 0.6910 \\
\hline R-squared & 0.595919 & Mean depenc & it var & 2.781847 \\
\hline Adjusted R-squared & 0.561425 & S.D. depende & var & 4.158162 \\
\hline S.E of regression & 2.753743 & Akaike info $\mathrm{c}$ & rion & 4.948487 \\
\hline Sum squared resid & 621.8144 & Schwarz crite & & 5.170692 \\
\hline Log likelihood & -214.6819 & Hannan-Quin & criter. & 5.038093 \\
\hline F-statistic & 17.27569 & Durbin-Watsc & & 0.657821 \\
\hline Prob(F-statistic) & 0.000000 & & & \\
\hline
\end{tabular}

Source: (Output Eviews Version 10, 2019)

\section{Note:}

Nilai Tukar: Exchange Rate

Tingkat Inflasi: Inflation Level

Fixed Effect Approach. The second approach of the panel data regression model is the Fixed Effect shown in Table 4 below: 
Table 4. Fixed Effect

\begin{tabular}{|c|c|c|c|c|}
\hline $\begin{array}{l}\text { Dependent Variable: FIRM_VALL } \\
\text { Method: Panel Least Squares } \\
\text { Date: } 10 / 03 / 19 \text { Time: } 21: 36 \\
\text { Sample: } 20142018 \\
\text { Periods included. } 5 \\
\text { Cross-sections included: } 18 \\
\text { Total panel (balanced) observatio }\end{array}$ & 5: 90 & & & \\
\hline Variable & Coefficient & Std. Error & t-Statistic & Prob. \\
\hline $\begin{array}{l}\text { INDEPENDENT_BOARD } \\
\text { INSTITUTIONAL_OWNERSHIP }\end{array}$ & $\begin{array}{r}-1.407543 \\
5.583316\end{array}$ & $\begin{array}{l}1.624004 \\
1.962658\end{array}$ & $\begin{array}{r}-0.866711 \\
2.844773\end{array}$ & $\begin{array}{l}0.3893 \\
0.0059\end{array}$ \\
\hline CSR & -3.844979 & 2.001296 & -1.921244 & 0.0591 \\
\hline DPR & -0.072508 & 0.218155 & -0.332368 & 0.7407 \\
\hline NILAI_TUKAR & -0.000369 & 0.000331 & -1.114644 & 0.2691 \\
\hline SIZE & -0.209445 & 0.600166 & -0.348978 & 0.7282 \\
\hline TINGKAT_INFLASI & -0.015548 & 0.095602 & -0.162635 & 0.8713 \\
\hline $\bar{c}$ & 10.94033 & 16.74736 & 0.653257 & 0.5159 \\
\hline & Effects $S p$ & cification & & \\
\hline Cross-section fixed (dummy varia & es) & & & \\
\hline $\begin{array}{l}\text { R-squared } \\
\text { Adjusted R-squared }\end{array}$ & $\begin{array}{l}0.972462 \\
0.962294\end{array}$ & $\begin{array}{l}\text { M ean depend } \\
\text { S.D. depende }\end{array}$ & $\begin{array}{l}\text { tt var } \\
\text { var }\end{array}$ & $\begin{array}{l}2.781847 \\
4.158162\end{array}$ \\
\hline S.E. of regression & 0.807429 & Akaike info or & rion & 2.640209 \\
\hline Sum squared resid & 42.37816 & Schwarz crite & & 3.334600 \\
\hline Log likelihood & -93.80939 & Hannan-Quin & criter. & 2.920228 \\
\hline F-statistic & 95.64145 & Durbin-Watso & & 2.558346 \\
\hline Prob(F-st atistic) & 0.000000 & & & \\
\hline
\end{tabular}

Source: (Output Eviews Version 10, 2019)

Note:

Nilai Tukar: Exchange Rate

Tingkat Inflasi: Inflation Rate

Random Effect Approach. The third approach of the panel data regression model is the Random Effect shown in Table 5 below: 
Table 5. Random Effect

\begin{tabular}{|c|c|c|c|c|}
\hline \multicolumn{5}{|c|}{$\begin{array}{l}\text { Dependent Variable: FIRM_VALUE } \\
\text { Method: Panel EGLS (Cross-section random effects) } \\
\text { Date: } 10 / 03 / 19 \text { Time: } 21: 42 \\
\text { Sample: } 20142018 \\
\text { Periods included: } 5 \\
\text { Cross-sections included: } 18 \\
\text { Total panel (balanced) observations: } 90 \\
\text { Swamy and Arora estimator of co mponent variances }\end{array}$} \\
\hline Variable & Coefficient & Std. Error & t-Statistic & Prob. \\
\hline $\begin{array}{l}\text { INDEPENDENT_BOARD } \\
\text { INSTITUTIONAL_OWNERSHIP }\end{array}$ & $\begin{array}{r}-3.657484 \\
4.897874\end{array}$ & $\begin{array}{l}1.538499 \\
1.687118\end{array}$ & $\begin{array}{r}-2.377306 \\
2.903102\end{array}$ & $\begin{array}{l}0.0198 \\
0.0047\end{array}$ \\
\hline $\operatorname{cs} \bar{R}$ & -2.778485 & 1.866588 & -1.488537 & 0.1404 \\
\hline DPR & 0.000153 & 0.212796 & 0.000719 & 0.9994 \\
\hline NILA__TUKAR & -0.000515 & 0.000320 & -1.609802 & 0.1113 \\
\hline SIZE & 0.326462 & 0.327043 & 0.998224 & 0.3211 \\
\hline TINGKAT_INFLASI & -0.015395 & 0.095492 & -0.161213 & 0.8723 \\
\hline & -1.440935 & 9.855643 & -0.146204 & 0.8841 \\
\hline \multicolumn{5}{|c|}{ Effects Specification } \\
\hline & & & S.D. & Rho \\
\hline Cross-section random & & & 2.571843 & 0.9103 \\
\hline Idiosyncratic random & & & 0.807429 & 0.0897 \\
\hline \multicolumn{5}{|c|}{ Weighted Statistics } \\
\hline R-squared & 0.191804 & \multirow{5}{*}{\multicolumn{2}{|c|}{$\begin{array}{l}\text { Mean de pendent var } \\
\text { S.D. dependent var } \\
\text { Sum squared resid } \\
\text { Durbin-Watson stat }\end{array}$}} & 0.386784 \\
\hline Ad ju sted R-squared & 0.122812 & & & 0.976468 \\
\hline S.E. of regression & 0.914544 & & & 68.58399 \\
\hline F-statistic & 2.780082 & & & 1.652483 \\
\hline Prob(F-statistic) & 0.012060 & & & \\
\hline \multicolumn{5}{|c|}{ Unweighted Statistics } \\
\hline $\begin{array}{l}\text { R-squared } \\
\text { Sum squared resid }\end{array}$ & $\begin{array}{l}0.168225 \\
1279.966\end{array}$ & \multirow{2}{*}{\multicolumn{2}{|c|}{$\begin{array}{l}\text { Mean de pendent var } \\
\text { Durbin-Watson stat }\end{array}$}} & $\begin{array}{l}2.781847 \\
0.088544\end{array}$ \\
\hline & & & & 0.088544 \\
\hline
\end{tabular}

Source: (Output Eviews Version 10, 2019)

Note:

Nilai Tukar: Exchange Rate

Tingkat Inflasi: Inflation Level

\section{Selection of Data Regression Panel Model}

Fixed Effect Test (Chow Test). Chow Test is a test of a model that will compare the Pooled Least Square (Common Effect) model and the Fixed Effect model. In this test the hypothesis is as follows:

\section{$\mathrm{H}_{0}$ : Model Common Effect \\ $\mathrm{H}_{1}$ : Model Fixed Effect}

$\mathrm{H} 0$ is rejected if the P-value is smaller than $\alpha$. Conversely, $\mathrm{H} 0$ is accepted if the P-value is greater than the value of $\alpha$. The $\alpha$ value used is 5\%. By using Eviews version 10, the result of data processing is as follows: 
Table 6. Result of Fixed Effect Test

\begin{tabular}{|c|c|c|c|}
\hline Effects Test & Statistic & d.f. & Prob. \\
\hline $\begin{array}{l}\text { Cross-section F } \\
\text { Cross-section Chi-square }\end{array}$ & $\begin{array}{r}52.281740 \\
241.745023\end{array}$ & $\begin{array}{r}(17,65) \\
17\end{array}$ & $\begin{array}{l}0.0000 \\
0.0000\end{array}$ \\
\hline
\end{tabular}

\begin{tabular}{|c|c|c|c|c|}
\hline $\begin{array}{l}\text { Cross-section fixed effects test e } \\
\text { Dependent Variable: FIRM_VALU } \\
\text { Method: Panel Least Squares } \\
\text { Date: } 10 / 04 / 19 \text { Time: } 17: 21 \\
\text { Sample: } 20142018 \\
\text { Periods included. } 5 \\
\text { Cross-sections included: } 18 \\
\text { Total panel (balanced) observatio }\end{array}$ & ation: & & & \\
\hline Variable & Coefficient & Std. Error & t-Statistic & Prob. \\
\hline INDEPENDENT_BOARD & -20.30426 & 2.498925 & -8.125197 & 0.0000 \\
\hline INSTITUTIONAL_OWNERSHIP & 1.019182 & 1.626213 & 0.626721 & 0.5326 \\
\hline $\begin{array}{l}\text { CSR } \\
\text { DPR }\end{array}$ & $\begin{array}{l}4.401753 \\
1.105321\end{array}$ & $\begin{array}{l}4.201385 \\
0.535882\end{array}$ & $\begin{array}{l}1.047691 \\
2.062619\end{array}$ & $\begin{array}{l}0.2979 \\
0.0423\end{array}$ \\
\hline NILAI_TUKAR & -0.000982 & 0.001054 & -0.932228 & 0.3540 \\
\hline SIZE & 0.546839 & 0.200329 & 2.729712 & 0.0078 \\
\hline TINGKAT_INFLASI & -0.016989 & 0.321242 & -0.052887 & 0.9580 \\
\hline $\bar{c}$ & 6.465469 & 16.20950 & 0.398869 & 0.6910 \\
\hline R-squared & 0.595919 & M ean depenc & t var & 2.781847 \\
\hline Adjusted R-squared & 0.561425 & S.D. depende & var & 4.158182 \\
\hline S.E. of regression & 2.753743 & Akaike info or & ion & 4.948487 \\
\hline Sum squared resid & 621.8144 & Schwarz crite & & 5.170692 \\
\hline Log likelihood & -214.6819 & Hannan-Quin & riter. & 5.038093 \\
\hline F-statistic & 17.27569 & Durbin-Watso & stat & 0.657821 \\
\hline Prob(F-st atistic) & 0.000000 & & & \\
\hline
\end{tabular}

Note:

Nilai Tukar: Exchange Rate

Tingkat Inflasi: Inflation Level

Based on the result of the Chow Test showed that the p-value $F$ test of 0,000 with a significance level of $5 \%(\alpha=0.05)$, then the p-value $(0.0000)<\alpha(0.05)$, therefore $\mathrm{H} 0$ (Common Effect Model) is rejected and the accepted is the fixed effect model.

Random Effect Test (Hausman Test). The purpose of the Hausman Test as a statistical test is to choose between Fixed Effect and random-effects models, which are the most appropriate. The Hausman test is carried out with the following hypothesis:

\section{$\mathrm{H}_{0}$ : Random Effect Model \\ $\mathrm{H}_{1}$ : Fixed Effect Model}

P-value $<0.05$ then $\mathrm{H} 0$ is rejected, the method chosen is a fixed effect. If $\mathrm{p}$ value $>0.05$ then the method we choose is a random effect. The result of these tests can be shown in the table below: 
Table 7. Test Result of Random Effect

\begin{tabular}{|c|c|c|c|c|}
\hline \multicolumn{5}{|c|}{$\begin{array}{l}\text { Correlated Random Effects - Hausman Test } \\
\text { Equation: RANDOM EFFECT } \\
\text { Test cross-section random effects }\end{array}$} \\
\hline \multicolumn{2}{|l|}{ Test Summary } & $\begin{array}{l}\text { Chi-Sq. } \\
\text { Statistic }\end{array}$ & Chi-Sq. d.f. & Prob. \\
\hline \multicolumn{2}{|l|}{ Cross-section random } & 0.000000 & 7 & 1.0000 \\
\hline \multicolumn{5}{|c|}{ - Cross-section test variance is invalid. Hausman statistic set to zero. } \\
\hline \multicolumn{5}{|c|}{ Cross-section random effects test comparisons: } \\
\hline Variable & Fixed & Random & Var(Diff.) & Prob. \\
\hline INDEPENDENT_BOARD & -1.407543 & -3.657484 & 0.270407 & 0.0000 \\
\hline INSTITUTIONAL_OWNERSHIP & 5.583316 & 4.897874 & 1.005660 & 0.4943 \\
\hline $\operatorname{cs} \bar{R}$ & -3.844979 & -2.778485 & 0.521037 & 0.1395 \\
\hline DPR & -0.072508 & 0.000153 & 0.002310 & 0.1306 \\
\hline NILAJ_TUKAR & -0.000369 & -0.000515 & 0.000000 & 0.0963 \\
\hline SIZZE & -0.209445 & 0.326462 & 0.253242 & 0.2869 \\
\hline TINGKAT INFLASI & -0.015548 & -0.015395 & 0.000021 & 0.9732 \\
\hline
\end{tabular}

\begin{tabular}{|c|c|c|c|c|}
\hline \multicolumn{5}{|c|}{$\begin{array}{l}\text { Cross-section random effects test equation: } \\
\text { Dependent Variable: FIRM_VALUE } \\
\text { Method: Panel Least Squares } \\
\text { Date: } 10 / 04 / 19 \text { Time: } 17: 35 \\
\text { Sample: } 20142018 \\
\text { Periods included: } 5 \\
\text { Cross-sections included: } 18 \\
\text { Total panel (balanced) observations: } 90\end{array}$} \\
\hline Variable & Coefficient & Std. Error & t-Statistic & Prob. \\
\hline $\begin{array}{l}\text { C } \\
\text { INDEPENDENT_BOARD } \\
\text { INSTITUTIONAL_OWNERSHIP } \\
\text { CSR } \\
\text { DPR } \\
\text { NILAN_TUKAR } \\
\text { SIZE } \\
\text { TINGKAT_INFLASI }\end{array}$ & $\begin{array}{r}10.94033 \\
-1.407543 \\
5.583318 \\
-3.844979 \\
-0.072508 \\
-0.000369 \\
-0.209445 \\
-0.015548\end{array}$ & $\begin{array}{l}16.74736 \\
1.624004 \\
1.982658 \\
2.001296 \\
0.218155 \\
0.000331 \\
0.600168 \\
0.095602\end{array}$ & $\begin{array}{r}0.653257 \\
-0.866711 \\
2.844773 \\
-1.921244 \\
-0.332368 \\
-1.114644 \\
-0.348978 \\
-0.162635\end{array}$ & $\begin{array}{l}0.5159 \\
0.3893 \\
0.0059 \\
0.0591 \\
0.7407 \\
0.2691 \\
0.7282 \\
0.8713\end{array}$ \\
\hline \multicolumn{5}{|c|}{ Effects Specification } \\
\hline \multicolumn{5}{|c|}{ Cross-section fixed (dummy variables) } \\
\hline $\begin{array}{l}\text { R-squared } \\
\text { Adjusted R-squared } \\
\text { S.E. of regression } \\
\text { Sum squared resid } \\
\text { Log likelihood } \\
\text { F-statistic }\end{array}$ & $\begin{array}{r}0.972462 \\
0.962294 \\
0.807429 \\
42.37616 \\
-93.80939 \\
95.64145\end{array}$ & $\begin{array}{l}\text { Mean depeno } \\
\text { S.D. depende } \\
\text { Akaike info cr } \\
\text { Schwarz crite } \\
\text { Hannan-Quin } \\
\text { Durbin-Watsc }\end{array}$ & $\begin{array}{l}\text { var } \\
\text { var } \\
\text { ion }\end{array}$ & $\begin{array}{l}2.781847 \\
4.158162 \\
2.640209 \\
3.334600 \\
2.920228 \\
2.558346\end{array}$ \\
\hline
\end{tabular}

Source: (EViews Output Version 10, 2019)

Note:

Nilai tukar: Exchange rate

Tingkat inflasi: Inflation level

Based on the Hausman test result, it showed a random cross-section p-value of $1.0000>0.05$ with a significance level of $5 \%$. Thus, it stated that the Random Effect Model is better than the Fixed Effect Model. 
Lagrange Multiplier Test (LM-Test). Lagrange Multiplier Test is conducted to determine the best method between the common effect or random effect. The hypothesis used is:

\section{$\mathrm{H}_{0}$ : Common Effect Model \\ $\mathrm{H}_{1}$ : Random Effect Model}

With the provisions: H0 is rejected if the value of Prob. Breusch-Pagan (BP-value) is smaller than the value of $\alpha$. Conversely, $\mathrm{HO}$ is accepted if the value is Prob. BreuschPagan (BP-value) is greater than the $\alpha$ value, the $\alpha$ value used is $5 \%$.

Table 8. Test Result of Lagrange Multiplier

\begin{tabular}{|c|c|c|c|}
\hline & \multicolumn{3}{|c|}{ Test Hypothesis } \\
\hline & Cross-section & Time & Both \\
\hline Breusch-Pagan & $\begin{array}{l}78.48733 \\
(0.0000)\end{array}$ & $\begin{array}{l}2.441859 \\
(0.1181)\end{array}$ & $\begin{array}{l}80.92919 \\
(0.0000)\end{array}$ \\
\hline Honda & $\begin{array}{l}8.859308 \\
(0.0000)\end{array}$ & $\begin{array}{c}-1.562645 \\
(0.9409)\end{array}$ & $\begin{array}{l}5.159520 \\
(0.0000)\end{array}$ \\
\hline King-Wu & $\begin{array}{l}8.859308 \\
(0.0000)\end{array}$ & $\begin{array}{c}-1.562645 \\
(0.9409)\end{array}$ & $\begin{array}{l}2.460552 \\
(0.0069)\end{array}$ \\
\hline Standardized Honda & $\begin{array}{l}10.20916 \\
(0.0000)\end{array}$ & $\begin{array}{c}-0.931214 \\
(0.8241)\end{array}$ & $\begin{array}{l}3.452952 \\
(0.0003)\end{array}$ \\
\hline Standardized King-Wu & $\begin{array}{l}10.20916 \\
(0.0000)\end{array}$ & $\begin{array}{c}-0.931214 \\
(0.8241)\end{array}$ & $\begin{array}{l}0.883630 \\
(0.1884)\end{array}$ \\
\hline Gourieroux, et al. * & - & - & $\begin{array}{l}78.48733 \\
(0.0000)\end{array}$ \\
\hline
\end{tabular}

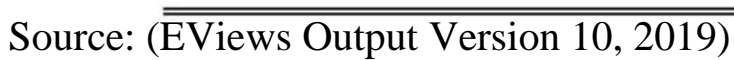

The Lagrange Multiplier Test result showed that the value of Prob. Breusch-Pagan (BP-value) of 0.0000 with a significance level of $5 \%(\alpha=0.05)$, then Prob. BP-value $(0.0000)<\alpha(0.05)$. Thus, H0 (Common Effect Model) is rejected, meaning, the accepted model is the Random Effect Model.

Formulation of Panel Data Regression Model. Based on the model test conducted, the model used in panel data regression in this study is the Random Effect model. The panel data regression test result uses the Random Effect model is presented in the following table: 
Table 9. Test Result of data Panel

\begin{tabular}{|c|c|c|c|c|}
\hline \multicolumn{5}{|c|}{$\begin{array}{l}\text { Dependent Variable: FIRM_VALUE } \\
\text { Method: Panel EGLS (Cross-section random effects) } \\
\text { Date: } 10 / 03 / 19 \text { Time: } 21: 42 \\
\text { Sample: } 20142018 \\
\text { Periods included: } 5 \\
\text { Cross-sections included: } 18 \\
\text { Total panel (balanced) observations: } 90 \\
\text { Swamy and Arora estimator of component variances }\end{array}$} \\
\hline Variable & Coefficient & Std. Error & t-Statistic & Prob. \\
\hline INDEPENDENT_BOARD & -3.657484 & 1.538499 & -2.377306 & 0.0198 \\
\hline INSTITUTIONAL_OWNNERSHIP & 4.897874 & 1.687118 & 2.903102 & 0.0047 \\
\hline $\begin{array}{l}\operatorname{CSR} \\
\mathrm{DPR}\end{array}$ & $\begin{array}{r}-2.778485 \\
0.000153\end{array}$ & $\begin{array}{l}1.866588 \\
0.212796\end{array}$ & $\begin{array}{r}-1.488537 \\
0.000719\end{array}$ & $\begin{array}{l}0.1404 \\
0.9994\end{array}$ \\
\hline NILAI_TUKAR & $\begin{array}{r}-0.000515 \\
0.326462\end{array}$ & 0.000320 & $\begin{array}{r}-1.609802 \\
0.998224\end{array}$ & 0.1113 \\
\hline TINGKAT_INFLASI & $\begin{array}{l}-0.015395 \\
-1.440935\end{array}$ & $\begin{array}{l}0.095492 \\
9.855643\end{array}$ & $\begin{array}{l}-0.161213 \\
-0.146204\end{array}$ & $\begin{array}{l}0.8723 \\
0.8841\end{array}$ \\
\hline \multicolumn{5}{|c|}{ Effects Specification } \\
\hline & & & S.D. & Rho \\
\hline $\begin{array}{l}\text { Cross-section random } \\
\text { Idiosyncratic random }\end{array}$ & & & $\begin{array}{l}2.571843 \\
0.807429\end{array}$ & $\begin{array}{l}0.9103 \\
0.0897\end{array}$ \\
\hline \multicolumn{5}{|c|}{ Weighted Statistics } \\
\hline $\begin{array}{l}\text { R-squared } \\
\text { Adjusted R-squared } \\
\text { S.E. of regression } \\
\text { F-statistic } \\
\text { Prob(F-statistic) }\end{array}$ & $\begin{array}{l}0.191804 \\
0.122812 \\
0.914544 \\
2.780082 \\
0.012060\end{array}$ & \multicolumn{2}{|c|}{$\begin{array}{l}\text { Mean dependent var } \\
\text { S.D. dependent var } \\
\text { Sum squared resid } \\
\text { Durbin-Watson stat }\end{array}$} & $\begin{array}{l}0.386784 \\
0.976468 \\
68.58399 \\
1.652483\end{array}$ \\
\hline \multicolumn{5}{|c|}{ Unweighted Statistics } \\
\hline $\begin{array}{l}\text { R-squared } \\
\text { Sum squared resid }\end{array}$ & $\begin{array}{l}0.168225 \\
1279.966\end{array}$ & $\begin{array}{l}\text { Mean depeno } \\
\text { Durbin-Watso }\end{array}$ & $\begin{array}{l}\text { t var } \\
\text { stat }\end{array}$ & $\begin{array}{l}2.781847 \\
0.088544\end{array}$ \\
\hline
\end{tabular}

Source: (EViews Output Version 10, 2019)

Note:

Nilai tukar: Exchange Rate

Tingkat Inflasi: Inflation Level

The panel data regression equation model formed in this study is the Random Effect model. Based on table 9 it can be shown the value of the coefficient constant so that the equation can be formed as follows: Firm Value $(\mathrm{Y})=-1.440935-3.657484(\mathrm{IB})+$ 4.897874 (IO) - 2.778485 (CSR) + 0,000153 (DPR) - 0,000515 (Exchange Rates) + 0.326462 (SIZE) - 0.015395 (Inflation Rate).

Classic assumption test. Because the panel data regression equation model generated from the model selection test is the Random Effect model, this does not require the classical assumption test (Indra, 2018). 


\section{Hypothesis test}

Coefficient of Determination. Based on the test result of the random effect model method, an Adjusted R2 (R-squared) value of 0.122812 is obtained. Thus, it can be seen that the variables of the Independent Board, Institutional Ownership, Corporate Social Responsibility, and Dividend Payout Ratio, Exchange Rates, Size, and The inflation rate can explain the Firm Value of $12.28 \%$, while the remaining $87.72 \%$ is influenced by other variables outside the variable. For the R Squared value obtained $19.18 \%$ value indicates that the influence of the independent variable on Firm Value is not strong, this is because $\mathrm{R}$ Squared has a correlation value $<0.50$.

F-Test (Simultaneous). Based on the test result of the random effect model method, it is obtained that the calculated $F$ value of 2.780082 with a probability of $0.012060<0.05$, thus the results of the analysis show that together the independent variables are Independent Board, Institutional Ownership, Corporate Social Responsibility, Dividend Payout Ratio, Exchange Rate, Size and Inflation Rate Affect Firm Value, so that the panel data regression model is feasible.

The T-test (partial). Based on the test result of the random effect model method in Table 4.8, there are 2 variables that affect Firm Value, namely the Independent Board variable with a probability of $0.0198<0.05$ negative direction and Institutional Ownership with a probability of 0.0047 where <of 0.05 and positive direction, while 5 other variables CSR (prob of 0.1404), DPR (0.9994), Exchange Rate (0.1113), Size (0.3211) and Inflation Rate (0.8723) wherein each probability> from 0.05 so it has no effect on Firm Value.

Summary of Hypothesis Test Result. Based on table 9 of the Individual Parameter Test Statistics, the following is a summary of the test results presented in table 10.

Table 10. Summary of Hypothesis Test Result

\begin{tabular}{l|l|l}
\hline \multicolumn{1}{c|}{ Hypothesis } & \multicolumn{1}{|c}{ Explanation } & \multicolumn{1}{c}{ Result } \\
\hline $\mathrm{H}_{1}$ & $\begin{array}{l}\text { Independent Board has a significant } \\
\text { positive effect on Company Value }\end{array}$ & $\begin{array}{l}\text { Independent Board has a significant } \\
\text { negative effect on Company Value }\end{array}$ \\
\hline $\mathrm{H}_{2}$ & $\begin{array}{l}\text { Institutional Ownership has a significant } \\
\text { positive effect on Company Value }\end{array}$ & $\begin{array}{l}\text { Institutional Ownership has a } \\
\text { significant positive effect on Company } \\
\text { Value }\end{array}$ \\
\hline $\mathrm{H}_{3}$ & $\begin{array}{l}\text { Corporate Social Responsibility } \\
\text { berpengaruh positive signifikan } \\
\text { terhadap Nilai Perusahaan. }\end{array}$ & $\begin{array}{l}\text { Corporate Social Responsibility does } \\
\text { not significantly influence Company } \\
\text { Value }\end{array}$ \\
\hline $\mathrm{H}_{4}$ & $\begin{array}{l}\text { Dividends have a significant effect on } \\
\text { Company Value }\end{array}$ & $\begin{array}{l}\text { Dividends do not have a significant } \\
\text { effect on Company Value }\end{array}$ \\
\hline $\mathrm{H}_{5}$ & $\begin{array}{l}\text { Exchange Rates have a significant effect } \\
\text { on Company Value }\end{array}$ & $\begin{array}{l}\text { Exchange Rates do not have a } \\
\text { significant effect on Company Value }\end{array}$ \\
\hline $\mathrm{H}_{6}$ & $\begin{array}{l}\text { SIZE has a significant effect on } \\
\text { Company Value }\end{array}$ & $\begin{array}{l}\text { SIZE has no significant effect on } \\
\text { Company Value }\end{array}$ \\
\hline
\end{tabular}




\begin{tabular}{l|l|l}
\hline $\mathrm{H}_{7}$ & $\begin{array}{l}\text { Inflation has a significant effect on firm } \\
\text { value }\end{array}$ & $\begin{array}{l}\text { The level of inflation has no } \\
\text { significant effect on firm value }\end{array}$ \\
\hline
\end{tabular}

Source: (Processed Data, 2019)

\section{DISCUSSION}

Effect of Independent Board on Company Value. The statistical result showed that the Independent Board variable has a significant negative effect on Firm Value, meaning that there is a negative influence between the Independent Board and Company Value, as the study (Zabri et all., 2016). This contradicts the statement that GCG is a system that regulates and controls the company in creating value-added for all stakeholders (Monks, 2003) which means there should be a positive influence between the Independent Board and Firm Value. This contradictory effect is caused by many factors, one of these factors, among others, is that in the activities of diverse and significantly complex manufacturing companies that require adequate proportions and competencies to be able to create added value, the number of relatively small proportions of IBs that may also have not been supported by an adequate level of competence that is unable to create added value for the company.

The Effect of Institutional Ownership on Company Value. Statistical result explained that Institutional Ownership has a significant positive effect on Company Value, this is consistent with the statement that the GCG mechanism, Institutional Ownership, is able to encourage the application of GCG principles namely Transparency, Accountability, Responsibility, Independence and Fairness so that it will create added value and increase Company Value (Amirudin et all., 2017), (Wan Yusof and Alhaji, 2012), (Monks and Minow, 2003) and in line with studies (Leksono and Vhaley, 2018), (Amirudin el all., 2017), (Iwan et all., 2016), (Sigit, 2015) (Sigit and Winwin, 2016).

Effect of Corporate Social Responsibility on Company Value. Statistical results explained that Corporate Social Responsibility does not significantly influence Company Value. This is contrary to stakeholder theory and (Hamidu et all., 2015) which stated that the concepts in CSR enable management to use CSR as a tool to increase profitability while increasing Company Value. This is likely that in manufacturing companies, CSR activities are usually standard according to regulations; each company in this sector is accompanied by an AMDAL analysis that is already standard so that it is not a determining factor for increasing Company Value.

Effect of Dividends on Company Value. Statistical result showed that the DPR has no significant effect on Company Value, this contradicts the statement that dividends are payments of a portion of profits from a company to shareholders, where dividend payments are one of the information awaited by shareholders because investors perceive that dividend payments are one indication of the company's financial health as a representation of Company Value (Rajhans, 2013) on the other hand the research controversy related to the effect of dividend policy on performance found in research (Ali et all., 2015), (Al Hasan et all., 2013) has a significant positive effect, (Ahmad et all., 2018) has a significant negative effect, while (Irandoost et all., 2013) with significant 
effect only in the short term, so the study of the influence of dividends on FV in manufacturing companies is still diverse. The dividend effect on FV cannot be caused by investors' perceptions also that the average manufacturing company is financially wellestablished, thus dividend payment is a matter that is usually not related to the financial health of the company.

Effects of Exchange Rates on Company Value. The result showed that Exchange Rates do not have a significant effect on Company Value, this is contrary to the general theory which stated that Exchange Rates affect Company Value, both positive and negative depending on the company's connectivity to import and export activities that show the intensity of the effect of Exchange Rates on Company Value. From the sample of manufacturing companies studied, the majority did not yet have a strong enough intensity on export and import activities and some had high intensity but eliminated each other so that the effect was not shown.

Effect of SIZE on Company Value. Statistical calculations explained that SIZE does not have a significant effect on Company Value, this is contrary to the statement that the greater the company the greater the opportunity to obtain additional revenue, due to the increasing number of activities that encourage added value (Dang and $\mathrm{Li}, 2015$ ). Data from descriptive statistics provide information that SIZE, as measured by Ln Total Assets, is relatively stable from year to year so that there is no change in sample company scale during the study period so that variations in Company Value are not caused by SIZE variables in line with research (Niresh and Velhampy, 2014) stated that SIZE has no effect on Company Value.

Influence of Inflation Rate on Company Value. Statistical calculations explained that the inflation rate has no significant effect on the value of the company, which is contrary to the statement that the inflation rate should affect the value of the company both positively and negatively. Studies related to the influence of Inflation Rate on Company Performance, in general, are still diverse, as studies (Zulfiqar and Ud Din, 2015) with result having a significant effect on Return on Assets (ROA) but not on Return on Equity (ROE), (Ifeanyi et all., 2016) there is a strong negative relationship between IT and Company Value (CV), but not ROA, (Rostami and Mosavi, 2016) stated that IT improves and increases company profitability. All of these impacts depend on the inflation rate which occurs in this study, the average inflation is $4 \%$ with a median of $3.3 \%$ during the observation year is an indication that the Inflation Rate on Company Value is not yet strong enough.

\section{CONCLUSION}

Conclusion. The influence of non-financial determinants is represented by variables Independent Board, Institutional Ownership, Corporate Social Responsibility, Dividend Payout Ratio, Exchange Rates, Size and Level of Inflation on Company Value only in small portions and not strong. Of all the independent variables, Institutional Ownership individually has a significant effect on Company Value, while the Independent Board variables, Corporate Social Responsibility, Dividend Payout Ratio, Exchange Rates, Size 
and Inflation Rate do not affect. This research implies that in the preparation of performance improvement strategies, company management is advised to consider nonfinancial factors namely Independent Board, Institutional Ownership, Corporate Social Responsibility, Dividend Payout Ratio, Exchange Rates, Size, and Inflation level.

Suggestion. It is recommended to policymakers to expand the legality of GCG and CSR activities so that the activities of GCG and CSR manufacturing companies have the potential to influence Company Value while impacting the community's environment. It is recommended to the next researcher to re-examine the non-financial variables of Company Value determinants by adding other variables and increase the duration of the study to obtain clear information on the direction of the influence of these variables on Company Value in manufacturing companies.

\section{REFERENCE}

Ahmad, Muhammad Akram; Salem Alrjoub, Ashraf Mohammad; Alrabba, Hussein Mohammad. (2018). The Effect of Dividend Policy on Stock Prices Volatility: Empirical Evidence from Amman Stock Exchange. Academy of Accounting and Financial Studies Journal, Vol 22, Number 2.

Amiruddin Jallo; Abdul Rahman Mus; Mursalim; Suryati. (2017).” Effect of CSR, GCG, Ownership Structure on Financial Performance and Firm Value: Study in Jakarta Islamic Index," IQSR Journal of Business and Management (IQSR-JBM) Volume 19, Issue 11.

Al Hasan, Md. Abdullah; Asaduzzaman; Al Karim, Rashed. (2013). The Effect of Dividend Policy on Share Price: An Evaluation Study. IQSR Journal of Economics and Finance, Vol 1, Issue 4.

Ali, Adnan; Ali Jan, Farzand; Sharif, Ilyas, (2015). Effect of Dividend Policy on Stock Prices. Business and Management Studies: An International Journal, Vol 3, Issue 1.

Al-Matari, Ibrahim Mohammed; Al-Swidi, Abdullah Kaid; Bt Fadzil, Faudziah Hanim (2014). The Measurements of Firm Performance's Dimensions. Asian Journal of Finance and Accounting, vol 6, No. 1.

Azutoru, Ibe Happy Chukwudike; Obinne, Ugwuanyi Georgina; Chineko, Okanya Ogochukwu, (2017). Effect of Corporate Governance Mechanisms on the Financial Performance of Insurance Companies in Nigeria. Journal of Finance and Accounting, Vol 5, No. 3.

Ayako, Aloys, and Walmawa, Fidelis, (2015). Determinants of Firm Value in Kenya: Case of Commercial Banks Listed at Nairobi Securities Exchange. Applied Finance and Accounting, Vol 1 Number 2.

Baba, Bello Usman, and Abdul Manaf, Kamarul Bahrain, (2016). Financial Ratios and Firm's Value: Evidence from Malaysian Listed. Advanced Science Letters, Volume 22, Number 5-6.

Brigham, Eugene F. dan Joel F. Houston, (2012). Dasar - Dasar Manajemen Keuangan Buku 1 Edisi 10. Jakarta, Salemba Empat.

Chen, Roger CY and Hsun Lee, Chen. (2017). The influence of CSR on firm value: an Application Of Panel Smooth Transition Regression On Taiwan. Journal of Applied Economics, Vol 49. Issue 34. 
Chin Kung, Fan, and Rupp, Nicholas G. (2018). Corporate Social Responsibility and Firm Value: Recent Developments. DOI: 105772/INTECHOPEN.76160.

Choi, Daeheon; Chung, Chune Young; Jung, Sangjun; Kim, Kyung Soon; Young, Jason. (2018). Corporate Social Responsibility and firm value: evidence from the Korean manufacturing industry. Transylvanian Review.

Chung, Chune Young; Jung, Sangjun; Young, Jason. (2018). Do CSR Activities Increase Firm Value? Evidence from the Korean Market. The article, Sustainability 10. 3164.

Dogan, Mesut. (2013). Does Firm Size Affect Firm Profitability? Evidence from Turkey. Research Journal of Finance and Accounting, Vol 4, No 4.

Dang, Chongyu (David); Li, Frank, (2015), Measuring Firm Size in Empirical Corporate Finance, Richard Ivey School of Business, University of Western, Ontario.

Gendro Wiyono, (2011). Merancang Penelitian Bisnis. Unit Penerbit dan Percetakan STIM YKPN Yogyakarta.

Hafez, Hassan M, (2016). Corporate Social Responsibility and Firm Value: An Empirical Study of An Emerging Economy. Journal of Governance and Regulation, Volume 5, Issue 4.

Hsin Lu, Yu; Fong Tsai, Chin, and Yen, David C. (2010). Discovering Important Factors of Intangible Firm Value by Association Rules. The International Journal of Digital Accounting Research, vol 10, pp 55-85.

Hamidu, Aminu Ahmadu; Haron, Harashid Md; Amran, Azlan, (2015), Corporate Social Responsibility: A Revie on Definitions, Core Characteristics and Theoretical Perspective, Mediterranean Journal of Social Sciences Vol 6 no 4, MCSER Publishing, Rome-Italy.

Hayes, Adam, (2019). Q Ratio- Tobin's Q, Article. Corporate Finance \& Accounting Financial Ratios.

Hyo Sang, Kim. (2018). How Do Exchange Rate Movements Impact Firm Performance in Korea., KIEP Opinion?

Indra Sakti, SM, (2018). Analisis Regresi Data Panel Menggunakan Eviews. Universitas Esa Unggul, Jakarta Barat.

Irma, and Widiastuti; Yeni and Hartati; Noorina and Muktiyanto, Ali. (2015). The Effect Good Corporate Governance Mechanism to Firm's Performance (Empirical Study of Manufacturing Firms Listed in IDX). Journal of Applied Business and Economic Research (IJABER).

Irandoost, Roza; Hassanzadeh, Rasoul Baradaran; Salteh, Heydar Mohammadzadeh. (2013). The Effect of Dividend Policy on Stock Price Volatility and Investment Decision. European Online Journal of Natural and Social Sciences.

Iwan Setiadi, Rahmawati, Djoko Suhardjanto, Djuminah. (2016). Board Independence, Environmental Disclosure and Firm Value,". Review of Integrative Business \& Economics Research, Vol 6, Issue 4.

Ifeanyi, Nando; Chukwuma C, Ugwu. (2016). An Empirical Analysis of Inflationary Impacts on Profitability and Value of Selected Manufacturing Firms in Nigeria. Research Journal of Finance and Accounting. Vol 7 No. 12.

Jamil, Sulaman; Tariq, Adnan; Asif, Mohsin; Afzaal, Naila; Anwar, Amna. (2016). The Impact of Corporate Governance Mechanism On Firm Performance In Pakistan. IQSR Journal of Economic and Finance Volume7, Issue 3.

John, Andrew, and Bernanke, Ben, (2005). Inflation. $5^{\text {th }}$ edition, Pearson, Washington. 
Kumar, T. Praveen; Priyadarsini, Kirupa, (2017). Assessing the Impact of Corporate Social Responsibility on Organizational Citizenship behavior in Banking Sector. Asian Journal of Research in Social Sciences and Humanities, Vol 7, No.1.

Karakus, Rifat and Bozkurt, Ibrahim. (2017). The Effect of Financial Ratios and Macroeconomic Factors on Firm Value: An Empirical Analysis in Borsa Istambul. Article on RSEP International Conferences on Social Issues and Economic Studies, Prague, Czechia.

Lee, Mihye. (2017). The Impact of Exchange Rate on Firm Performance: Evidence from Korean Firms. Journal Emerging Markets, Finance, and Trade, Vol 53, Issue 11.

Luqman S, Olawale; Bamidele M, IIo; Fatai K, Lawam. (2017). The Effect Of Firm Size On The Performance Of Firms In Nigeria. The IEB International Journal of Finance.

Lela Nurlaela Wati. (2018). Metodologi Penelitian Terapan. CV PUSTAKA AMRI, Jakarta.

Monks, Robert AG and Minow, N. (2003). Corporate Governance. 3 rd Edition, Blackwell Publishing.

Nadya Marsha dan Isrochmani Murtaqi. (2017).The Effect of Financial Ratios on Firm Value In The Food and Beverages Sector on the IDX. Journal Of Business and Management, vol 6 No. 2 pp 214-226.

Nagahisarchoghaei, Mohammad; Ngahi, Morteza; Soleimani, Nadia. (2018). Impact of Exchange Rate Movements on Indian Firm Performance. International Journal of Finance and Accounting, 7(4).

Niresh, Alloy, and Velhampy, T, (2014), Firm Size and Profitability: A Study of Listed Manufacturing Firms in Sri Lanka, International Journal of Business and Management, Vol 9, No. 4.

Okika Christian EM; Udeh, Francis N.P; Okoye Greg. O. (2018). Effect of Exchange Ratre Fluctuation on Firm Profitability: Evidence from Selected Quoted Conglomerates in Nigeria. International Journal of Academic Research in Business \& Social Sciences.

Oyelade, Aduralere Opeyemi. (2019). The Impact of Firm Size on Firm Performance n Nigeria: A Comparative Study of Selected Firms in The Building Industry in Nigeria, Asian Development Policy Review, Vol 7, No 1, 1-9.

Oyong Lisa. (2017). Company Value Determinant Study on Manufacturing Company Listed in Indonesia Stock Exchange. Jurnal Ilmiah Bidang Akuntansi dan Manajemen, vol 14, no 2.

Rajhans, Rajni Kant, (2013). Financial Determinants of Firm's Value: Evidence from Indian Firms. Zenith International of Business Economics \& Management Research, Vol 3 (5).

Rostami, Saeed; Mosavi, Alireza, (2016). A Study on Effect of economic openness and Inflation On Profitability In The Banks Listed On The Tehran Stock Exchange. International Journal of Humanities and Culturasl Studies.

Santos, Juliana Bononi and Brito, Luiz Artur Ledur (2012). Toward Subjective Measurement for Firm Performance. Brazilian Administration Review, V. 9, Special Issue, art 6. 
Selvarajah, Dilashenyi Devi; Murthy, Uma; Massilamany, Mathavi, (2018), The Impact of Corporate Social Responsibility on Firm's Financial Performance in Malaysia, International Journal of Business and Management, Vol 13, No 3.

Sigit Sukmono, (2015). "Effect of the board of Commissioners of its value through the quality of financial reporting. International Journal of Science and Technology Research, Vol 4 issue 04.

Sigit Sukmono and Winwin Yadiati. (2016). "Effect Of The Board Of Commissioner And Audit Committee On The Firm Value With Mediating Effect Financial Reporting Quality".

Sucuahi, William and Cambarihan, Jay Mark (2016). Influence of Profitability to the Firm Value of Diversified Companies in the Philippines. University of Mindanao, Philippines.

Suryanto and R. Meisa Dai. (2016). "GCG, Capital Structure, and Firm Value: Empirical studies on Food and Beverage Companies in Indonesia. European Journal of Accounting, Auditing and Finance Research, Vol 4 no 11.

Wan Yusof, Wan Fauziah, and Alhaji, Idris Adamu, (2012). Insight of Corporate Governance Theories. Journal of Business \& Management, Volume 1, Issue 1.

Williams, Harley Tega. (2018). An Empirical Investigation of The Impact of Exchange Rate Fluctuations on The Performance of selected Listed Firms in Nigeria. Journal of Business Management and Economic Research, Vol 2, Issue 3.

Wiwik Utami, (2015). Financial Performance and the Quality of Sustainability Disclosure Based on Global Reporting Initiative: Value Relevances Study in Indonesia Stock Exchange. Mediterranean Journal of Social Sciences, Vol 6, No.5.

Yisau Abiodene, Babalola, (2013), The Effect of Firm Size on Firms Profitability in Nigeria, Journal of Economics and Sustainable Development, Vol 4, No 5.

Zulfiqar, Zuhaib, and Ud Din, Nizam, (2015). Inflation, Interest Rate, And Performance: The Evidence From The Textile Industry Of Pakistan. International Journal of Arts and Commerce, Vol 4. No 2.

Zabri, Shafie Mohamed; Ahmad, Kamilah; Wah, Khaw Khai, (2016). Corporate Governance Practices and Firm Performance: Evidence from Top 100 Public Listed Companies in Malaysia. Procedia Economics and Finance, Vol 35. 